\title{
Socio-economic Status of Gandharva Community Living in Batulechaur, Pokhara
}

\author{
Ananta Raj Dhungana \\ School of Development and Social Engineering, Pokhara University \\ Email: anantastat@gmail.com \\ Kishor Chapagain
}

\begin{abstract}
This study aims to explore the socio-economic status of Gandharva community. For this purpose, the household heads of all the fifty households of Gandharva community of Batulechaur in Pokhara were interviewed by using structured questionnaire. Descriptive statistics was used for analyzing the information gathered from the respondents. The study focused on socio-economic status and occupational shift of Gandharva community. The study found that the Gandharva community is socially marginalized and relatively poor in comparison to other communities. Their living status is not good. They have low education and low income profession as reason. For this reason most of them have shifted their occupations from singing and dancing to others like service sector, unskilled job, foreign employment in golf countries and some small business like running shops, vegetable selling, ect.
\end{abstract}

Keywords: Gandharva Community, Living status, Marginalized, Occupation, Singing

\section{Introduction}

More than hundred castes and ethnic groups are living in Nepal. Among these, 26 caste groups are considered as Dalit communities which are further divided into two groups based on regional origin like mountainous/ hilly and plain/ Tarai (NDC, 2016). Among these Dalits, Gandharva or Gaine is one of the Dalit castes living in hilly region. Mainly, Gandharva are inhabit in the western hill districts like Lamjung, Tanahun, Kaski, Baglung, etc. According to the census of 2011, the total population of the Gaine is 6791. Gaines are famous for their diverse and floating cultural life. A large number of Gaine population have been migrated to Tarai. However, this study is flcused only on in search for livelihood (NDC, 2016). This study focused on only the Gandharva of Batulechaur, Pokhara, since the place has the largest concentration of Gandharva people. There are around 50 households of
Gandharva in Batulechaur, Pokhara with total population 375.

Gandharva people sing folksongs that have been never written but passed verbally from person to person from generation to generation. Their songs reflect the feeling of sorrow resulting from death and disasters which were faced specially by rural people. The main economic source of Gandharva people was singing, and dancing in the past. Even now some of them have the same source of income for their livelihood. As a result of modernization in different sectors, urbanization process is going rapidly. For this reason people have interest towards the modern songs and musical instruments. The modern means of communication like T.V., Radio have minimized the importance of Gandharva's folksongs and sweet music of Sarangi. Their traditional occupation of singing, dancing and begging is also not liked by modern society (Macdonald,

Journal of Development and Social Engineering

Volume 3 | Number 1 | December 2017, 9-16

ISSN 2382-5332 @ School of Development and Social Engineering, Pokhara University 
1975). These factors have been hindering seriously to their source of income. It is believed that the Gandharva sang the heroic songs to encourage the army to show their bravery in the battlefield. In course of time their socioeconomic status was gradually degraded due to the various reasons.

Nepal is a multiethnic, multi-cultural, multi religious and multi linguistic country. Due to it's geographical and sociocultural diversity, it is a fertile land for socio anthropological research (Gurung, 1989). Bista (1970) has described almost all the castes and ethnic groups of Nepal. Also, he described their custom, belief and cultural life in brief. Gautam and Thapa Magar(1994) have attempted to highlight the brief description of Gaine of Nepal in their book entitled Tribal ethnography of Nepal, Vol. II (1994). In this book they described Gaine's inhabiting districts, their physical characteristics, their septs. They tried to describe the Gaine of Nepal with reference to the historical background. Also, they attempted to highlight Gaine's cultural life, social belief as well as economic status.

Gautam and Thapa Magar (1994) also have traced about some untouchable castes of Nepal. Badi, Dom, Gaine, Kami, Musahar Sarki, Halkhor etc. are some of the untouchable castes they have tried to describe.

The word Gaine indicates that they are the professional signers. The word 'Gandharva' is mentioned in our holybooks like Ramayan, Mahabharat and other epic literatures. In these literatures Gandharva is mentioned as a musician of Indra, a Hindu god. According to Yogi Narahari Nath, there was an existence of Gaines in Karnali Pradesh in around sake Era 1279. It is supposed that the Gaine of Jumla area gradually migrated to the eastern part of the country during the medieval period. Also, Hira Gaineni was a good singer who sang the songs on the bravery of Mathvar Sing Thapa. Gaine themselves say that it was only under the rule of Ranas that their position deteriorated to the point where they became one of the lowest castes (Macdonald,
1975). The historicity of the Gaine is thought to be related to the Bhat and Badi of Karnali Pradesh. Most of the Gaine agree with the fact that they have strong sense of affinity with badi and Bhat communities of western Nepal (Darnal, 2043).

It has been already mentioned that there are very few sociological and Studies on the lowest (Dalit) castes in Nepal. Sociologists and anthropologists have not done sufficient studies about the Gaine community. Kantipur, a Daily newspaper (5 May, 2005) has stated the Gaine are occupational caste. Their traditional norms and customs allow marrying in childhood. They eat meat of pigs and drink wine necessarily. Kantipur, Daily Newspaper (6 June, 2005) has stated the Surname of the Gandharva. They are living in western regions. They are doing early marriage now. But some NGOs/INGOs are working to promote the lifestyle of the Gaine community by doing different programs like as counseling to do marriage in adult, educating programs etc. Nepal government (2002) has stated the Gaine are considered the lowest untouchable caste groups. If any member of the high caste Hindu group is ever touched accidentally by them, he/she must purify either by sprinkling "gold water" or taking bath in the pond as well. Even today Gandharva are not allowed to fetch water either form the private or public tube-wells. They have separate tube wells for their own use or go to the nearby stream to fetch water. Regarding their origin, the Gandharva have their own ideas and believes. Most of the Gandharva claim that they are the descendants of the Gandharva a musician of Indra, a Hindu god. According to their version, Brahmaji the creator, created four Rishis (hermits). Among these four Rishis there was one Rishi called Gandharva, who was less cunning than his colleague. So, other three Rishis wanted to remove him from their group. For this, they consulted each other and they gave him a leg of a cow and told him to beg for alms uttering the word "Awariha". The simple minded Gandharva Rishi did what he 
was told to do. On returning with alms, he was told that he had defiled himself because he had used the leg of cow and so from then he was to continue his life as a beggar. Thus it is believed that Gandharva is the progenitor of the Gaine and since he was defiled the Gaines by birth are regarded as low caste today. The stringed musical instrument called the 'Aarwajo' which they use to provide music while they sing also originated (Gautam and Thapa Magar, 1994).

Gandharvas have their own language as other community which is known as Parsi similar to Damai and Kami. It is mainly used to communicate within community and inter personal as well to keep something secret in front of other language speaking people. But to communicate with other community people, they prefer to use Nepali considering a common field of experience. At present many more changes are taking place. Their language behavior has been changed. Their lifestyle has also been changed. The young generation hardly use their own language but prefer to use Nepali language instead. The old generations suggest them to continue their traditional occupation but the young generations have rejected their suggestions. (NNDSWO, 2005)

It seems to be a great confusion about the origin district of Gandarava society in Nepal. No reliable graphical source has been found as yet. Certain researchers claimed that Kaski is the original place of Gandarva people and locals think that Batulechaur is the ancient place of the Gaine and they have been living over there for generation to generation. Many of them also claim Gandharva community started to live in Batulechaur area in the reign of Kulmandan Shah. According to 76 years old female Gaine Nainkala Gayak, the first settlement of Gandharva was at Pathan of Badhar bott and people back then were involved in rearing pigs. Although many locals claim Batulechaur as the origine of Gandharvas in the context above, but the real truth seems different. Names like those of Maniram and Hiradevi Gaine of Gorkha are found mentioned during the unification process of Nepal by king Prithivi Narayan Shah (NNDSWO, 2005).

Gandhrava live in remote area of Nepal, so all the people of that area engage in different occupation. Gandharva has own works, singing, dancing, fishing, laboring and so on. So their condition is not so well. After declaration of republic democratic Nepal, Gandharva engage in different field having simple works. Some serve in Hotel, hospital and in other offices as low grade workers. Because of being uneducable they are not able to be employee in higher rank (Wordpress, 2016).

In terms of population and socioeconomic development Gaines is the most marginalized caste among the Dalits communities. By the order of the first National Civil Code 1854 (Muluki Ain, 1910 BS) Gaine is listed at the bottom of intra Dalits caste hierarchy. According to the 1991 census, the number of Gaines was 4,484 . Now, the latest census 2011 shows there are 6791 Gaines in Nepal. This is 0.03 Percent of total Dalit population (3710575) of the country. Though, more or less Gaines are scattered over all the country but the large population of Gaines are found in Batulechaur of Kaski. National Dalit Strategy Report 2002 states the population of Gaine with more than 200 in number is observed only in seven districts (Dang, Kaski Chitwa,Pyuthan, Gulmi, Surkhet, Tanahun). The literacy rate of Gaine was 31.3 compared the national average of 39.6 per cent whereas the overall literacy rate of Dalit was only 22.8 percent in the 2002 (Wagle, 2015).

According to the census of 2011, in western development region, there is a maximum population of Gaine as compared to the other development regions. Similarly, in Far Western development region, the population of Gaine is minimum as compared to the other development regions. It has been observed that the Gandharvas of Batulichaur of Kaski have been changing their occupation and lifestyle. Further, Still 
there is no research specially focused on the Gandharva of Batulichaur, Kaski regarding their socio-economic status and occupational shift. Hence this study tried to explore the socio-economic status and occupational shift of these people.

\section{Data and Methods}

On the basis of population of Gaine, Kaski district ranks at a second largest district. The total population of Batulechaur is 376 . In total there are around 50 households of Gadharva at Batulechaur, Pokhara. Due to the largest and compact settlement, Gandharva community of Batulehaur is considered as an appropriate place for the study of socioeconomic status of Gandharva. As this study has tried to explore the socio-economic status of Gandharva community, both descriptive as well as exploratory research design was adopted for this study. Further, all the fifty housholds of Gandharva community of Batulechaur, Pokhara were selected for this study. The interview was carried out from the household head of these communities. Structured questionnaire was used for collecting the information. Descriptive statistics was used for analyzing the data.

\section{Results and Discussion}

Based on the information gathered from fifty household head, we have the following findings:

\section{Socio-demographic Characteristics of the Respondents}

In this section, socio-demographic variables like age, sex, religion, marital status, types of Marriage, education, family type, and family size of the respondents were analyzed (table 1). More than half (54\%) of the respondents are from age group up to 40 years. Majority (58\%) are male. The respondents from joint family are slightly more than that of Nuclear family. Similarly more than two third of the respondents have large family size. Majority of the respondents are married, few are widow/widower and divorced. Another component of the study is the marriage pattern. This study shows that more than half $(52.0 \%)$ have married with arrange while the remaining have love marriage.

Table 1: Social and demographic characteristics of the respondents

\begin{tabular}{lcc}
\hline Variables & Number & Percent \\
\hline Age group (years) & 27 & 54.0 \\
$\quad$ Upto 40 years & 23 & 46.0 \\
$\quad$ Above 40 years & 29 & 58.0 \\
\hline Sex & 21 & 42.0 \\
$\quad$ Male & & \\
$\quad$ Female & 24 & 48.0 \\
\hline Family type & 26 & 52.0 \\
$\quad$ Nuclear & & \\
$\quad$ Joint & 15 & 30 \\
\hline Family Size & 35 & 70 \\
$\quad$ Small(less than or equal to 4 & & \\
$\quad$ Large (more than 4) & 40 & 2.0 \\
\hline Marital status of Respondent & 1 & 18.0 \\
$\quad$ Married & 9 & 48.0 \\
$\quad$ Divorce & & 52.0 \\
$\quad$ Widow/Widower & 24 & $\mathbf{1 0 0}$ \\
\hline Types of marriage & 26 & $\mathbf{5 0}$ \\
$\quad$ Love & & \\
$\quad$ Arrange & & \\
\hline Total & & \\
\hline
\end{tabular}

Source: Field Survey, 2017 


\section{Upper Caste's Treat}

Our social system is based on the caste system or caste hierarchical system has created many problems. One of them is social inequality. By the civil code of 2020 B.S., it has abolished all kinds of social discrimination based on caste system. But, in practice the caste hierarchy is still strictly followed within the caste groups. The Gandharva are also treated as an untouchable caste in Nepal. Gandharva of Batulechaur, Pokhara are living within the periphery of high caste settlement. Their settlement is totally concentrated at one corner of Batulechaur.

Table 2 shows that almost nine tenth of the respondents responded that the upper caste's relation with them are friendly whereas very few of the respondents are treated as respectful by upper caste people. It shows that most of their relationship is friendly with high caste people. With awareness and modernization of time dominating nature of upper class people is not found in this case, and none of the respondents feel dominated by upper caste people.

\section{Table 2: Behavior of high caste people} with Gandharva

\begin{tabular}{lcc}
\hline Response & Number & Percentage \\
\hline Respectful & 6 & 12.0 \\
Friendly & 44 & 88.0 \\
\hline Total & $\mathbf{5 0}$ & $\mathbf{1 0 0 . 0 0}$
\end{tabular}

Source: Field Survey, 2017

Socio-economic Status of the Respondents It covers the different socio-economic characteristics of the respondents. Table 3 shows that literate respondents (48\%) cover less percentage than illiterate (52\%). Nine tenth of the respondents are from Hindu religion while rest (10\%) follows the Christian religion. Almost three fourth of the respondents have annual income between Rs. 20000 to Rs. 40000 and eighteenth percent of the respondents have annual income below Rs. 20000. Further only eight percent of the respondents have their annual income as above Rs. 40000. It is also found that majority of the respondents i.e. 58.0 percent, have their saving account in the bank while 42.0 percent of the respondents still don't have their saving accounts in the bank. Almost one third of the respondents have loan. Most of their loan is for household expenses and other remaining is for medical checkup and rearing goats and chickens.

\section{Table 3: Socio-economic status of the respondents}

\begin{tabular}{lcc}
\hline Variables & Number & Percentage \\
\hline Education status & & \\
$\quad$ Literate & 24 & 48.0 \\
$\quad$ Illiterate & 26 & 52.0 \\
\hline Religion & & \\
$\quad$ Hindu & 45 & 90.0 \\
$\quad$ Christian & 5 & 10.0 \\
\hline $\begin{array}{l}\text { Annual Income (in Rs.) } \\
\quad \text { Below 20000 }\end{array}$ & 9 & 18 \\
$\quad$ 20000-40000 & 37 & 74 \\
$\quad$ Above 40000 & 4 & 8 \\
\hline $\begin{array}{l}\text { Saving accounts } \\
\quad \text { Yes }\end{array}$ & 29 & 58.0 \\
$\quad$ No & 21 & 42.0 \\
\hline $\begin{array}{l}\text { Loan } \\
\quad \text { Yes }\end{array}$ & 15 & 30.0 \\
$\quad$ No & 35 & 70.0 \\
\hline $\begin{array}{l}\text { Purpose of loan } \\
\text { For medical checkup }\end{array}$ & 2 & 4.0 \\
For house hold ex- & 12 & 24.0 \\
penses & & \\
For rearing goats, & 1 & 2.0 \\
chickens & & \\
\hline Total & $\mathbf{5 0}$ & $\mathbf{1 0 0}$ \\
\hline Sol Field Survey, 2017 &
\end{tabular}

Source: Field Survey, 2017

School-going Children of the Respondents by Sex Among 103 school-going children, majority (56.31\%) of the children are male followed by female (43.69\%). Further, almost all the school-going children study in boarding school nearby the community. This may be due to the awareness through their education. So, the number of school-going girls has also been increasing and is almost the same as school going boys. 
Table 4: School-going children by sex

\begin{tabular}{lcc}
\hline Sex & $\begin{array}{c}\text { No. of School- } \\
\text { going Children }\end{array}$ & Percentage \\
\hline Boys & 58 & 56.31 \\
Girls & 45 & 43.69 \\
\hline Total & $\mathbf{1 0 3}$ & $\mathbf{1 0 0 . 0 0}$ \\
\hline
\end{tabular}

Source: Field Survey, 2017

\section{Household Physical Infrastructure}

It is found that majority of the respondents (92.0\%) have their own house and the respondents who live in rented house are only 8.0 percent. The entire respondents have toilet in their house. Almost all the respondents have normal toilet and very few of the respondents have toilet with flush without safety tank. More than nine tenth (92\%) of the respondents have their house with tin roof followed by concrete roof house (8\%). Except few respondents, almost all have access of drinking water in their house and all are using tap water as their sources of water (Table 5). It seems that either they are not aware about safety tank or they don't have space to make the safety tank.

Table 5: Household physical infrastructure

\begin{tabular}{lcc}
\hline Variables & Number & Percentage \\
\hline Types of House & & \\
Own House & 46.0 & 92.0 \\
Rented House & 4.0 & 8.0 \\
\hline Having toilet & & \\
Yes & 50 & 100.0 \\
\hline $\begin{array}{l}\text { Type of toilet } \\
\text { Normal }\end{array}$ & 48 & 96.0 \\
$\begin{array}{l}\text { Having flush with- } \\
\text { out safety tank }\end{array}$ & 2 & 4.0 \\
\hline $\begin{array}{l}\text { Type of Roof } \\
\text { Tin Roof }\end{array}$ & 46 & 92.0 \\
Concrete Roof & 4 & 8.0 \\
\hline $\begin{array}{l}\text { Access to drink- } \\
\text { ing water }\end{array}$ & & \\
Yes & 49 & 98.0 \\
No & 1 & 2.0 \\
\hline Total & $\mathbf{5 0}$ & $\mathbf{1 0 0}$ \\
\hline Source: Field Survey, 2017 &
\end{tabular}

Facility from VDC, Birth Registration and Participation in Election

It is found that except few respondents; almost all other respondents are not getting any facilities from VDC. Majority of the respondents (88\%) have done birth registration while 12.0 percent do not have their birth registration. Further, It is found that more than three fourth $(78.0 \%)$ of the respondents have participation for voting in last election while 22.0 percent have not participated for voting in last election during that time (Table 8). It means that most of them are aware about the political situation regarding the voting right for election.

Table 6: Facility from VDC, birth registration and participation in election

\begin{tabular}{lcc}
\hline Variables & Number & Percentage \\
\hline Facility from VDC & & \\
Yes & 1 & 2.0 \\
No & 49 & 98.0 \\
\hline Birth registration & & \\
Yes & 44 & 88.0 \\
No & 6 & 12.0 \\
\hline Voting in election & & \\
Yes & 39 & 88 \\
No & 11 & 22.0 \\
\hline Total & $\mathbf{5 0}$ & $\mathbf{1 0 0}$ \\
\hline Sol
\end{tabular}

Source: Field Survey, 2017

\section{Intra- caste Marriage and Prefer after Marriage}

Table 7 shows about the condition of marriage with other culture of caste peoples. In this community intra - caste marriage is not a new phenomenon. It is found that more than half of the respondents have no any intra-caste marriage in their family members while the remaining 46 percent have intracaste marriage by different members of the family like as son, brother and sister of the respondent by him or herself. Four fifth of the respondents prefer birth of any one i.e. baby boy or baby girls after marriage. Sixteen percent of the respondents prefer birth of son after marriage while only 4 percent prefer birth of daughter after marriage. 
Table 7: Intra- caste marriage in family and prefer after marriage

\begin{tabular}{lcc}
\hline Variables & Number & Percentage \\
\hline Intra- caste & & \\
Marriage & & \\
Yes & 23 & 46.0 \\
No & 27 & 54.0 \\
\hline
\end{tabular}

Preference of

child by sex

Son

Daughter

Any one

Total

Source: Field Survey, 2017

\section{Occupation of the Respondents}

Table 8 shows the current occupation status of the respondents, it shows that more than two third of the respondents are involved in service as their occupation, followed by others $(16 \%$, i.e. in beauty parlors, sewing, foreign employment, poultry etc.), wage (12\%), and singing song (4\%). It shows that most of the household's main source of income is service in various sectors. Further It also shows that their main traditional occupation of singing and begging have been overlapped by other sources of income, most of the respondents don't want to continue their traditional occupational as income source as far they want to shift to other sources of income generation occupation rather than their traditional occupation.

Table 8: Occupation of the respondents

\begin{tabular}{lcc}
\hline Occupation & Number & Percent \\
\hline Singing & 2 & 4.0 \\
Wage & 6 & 12.0 \\
Service & 34 & 68.0 \\
Other & 8 & 16.0 \\
\hline Total & $\mathbf{5 0}$ & $\mathbf{1 0 0 . 0}$ \\
\hline Source: Field Survey
\end{tabular}

Source: Field Survey, 2017

\section{Changing Shift in Occupation}

In this unit changing pattern of occupation with respect to time is described. It is found that majority $(80.0 \%)$ of the respondents have changed their occupation while 20.0 percent of the respondents have not changed their occupation during the last 10 years (table 9).
Table 9: Change in Occupation during last 10 years

\begin{tabular}{lcc}
\hline Change & Number & Percentage \\
\hline Yes & 40 & 80 \\
No & 10 & 20 \\
\hline Total & $\mathbf{5 0}$ & $\mathbf{1 0 0}$ \\
\hline
\end{tabular}

Source: Field Survey, 2017

It is found that majority of the respondents whose previous occupation was singing a song with sarangi has changed their occupation during the last ten years which is similar to Dhungana and Khadka (2013), which is the study of Badi people of Surkhet district regarding their occupational shift. Most of the respondents are involved in wage labour and services while very few of the respondents are now involved in business. It may be due to the poverty and peoples' look (behave/ perception) over them as low caste. Their traditional occupation is not liked very much by modern society. Due to the rapid urbanization, the people seem more interested in western music and songs which are popularized by modern means of communication like Radio and TV channels. As a result, the Gaine's folk songs and sweet music of Sarangi are being neglected by people.

\section{Conclusion}

Although majority of the respondents are Hindu, there are also some respondents who are Christian. The proportion of literate and illiterate respondents is almost the same. Majority of the respondents have their family members with size four or more. Majority of the respondents have saving account and do not have any loan. The number of school going girls is also satisfactory. It may be due to awareness through education. The Gandharva community is not aware about the safety tank for their toilet. Almost all are not getting any facilities from the VDC. Most of them have birth registration. Most of them are aware about the political situation of the country and casted their vote in latest election. It is found that most of the Gandharva's relationship is friendly with high 
caste people. They have inter-caste marriage practice within their family member. They have open choice regarding the preference of birth by sex after marriage. Modernizing elements of society like communication, transportation and education have changed the society. No society remains constant. While looking at the social, cultural and economic life of Gandharva of Batulechaur, one can see the changes taking place in this community. Being an urban settlement, nowadays in this community positive attitude towards education have been traced out. They are giving priority for the school education to their children. They feel humiliated when anyone calls them "Gaine". Instead of this word they like to hear calling them "Gayak" or "Gandharva".

Further, the number of school- going girls is increasing. They are somehow influenced by the education. Economy is one of the deciding factors of social change. The economic life of Gandharva of Batulechaur is mainly based on various occupations. Singing and dancing is also their traditional occupation but which is not liked very much by modern society. Due to the rapid urbanization, the people seem more interested in western music and songs which are popularized by modern means of communication like Radio and TV channels. As a result, the Gaine's folk songs and sweet music of Sarangi are being neglected by so called modern people.

The traditional occupation of Gaine people is badly affected due to modernization of the society. Keeping the professional problem in mind, majority of the respondents are seeking other occupation for better life. By the influence, they are interested and seeking some others prestigious jobs and they have shifted their occupation towards services and other sectors like beauty parlors, sewing, foreign employment, poultry. It may be due to the poverty and peoples' look (behave/perception) over them as low caste.

\section{Acknowledgement}

The study is based on the data collected for the Master's Degree dissertation of the second author. The dissertation has been submitted to the School of Development and Social Engineering, Faculty of Humanities and Social Sciences, Pokhara University in 2017.

\section{References}

Bista, D. B. (1970). People of Nepal. Kathmandu: Ratna Pustak Bhandar.

Bista, D. B. (1972). Sabai Jatko Fulbari. Kathmandu: Sajha Prakashan.

CBS, (2011). Social Charastristics Table. Centra Bureau of Statistics, Kathmandu.

Chhetri (Bista), G. (2042). Batulechaur Pokhara Ka Gaine Jati Ko Samajik Aarthik Aaddayan, Unpublished dissertation submitted to Faculty of Humanities and Social Science, Tribhuvan University, Kathmandu.

Dhungana, A. R., and Khadka, K. (2013). Socio-economic Status and Occupational Shift among Badi People in Chinchhu VDC, Surkhet District, Nepal. Journal of Economics and Management. 1(1): 31-44.

Darnal, R. S. (2043 B.S.). "Nepali Lok Geet RA Gaine”. Pragya 4.55: 29-34.

Gautam, R. and Thapa, Magar, A. K. (1994). Tribal Ethnography of Nepal Vol. II Book Faith, India.

Gurung, G. (1989). The chepang a study in continuit.

Macdonald, A. W. (1975). The Gaine of Nepal: The Ethnology of Nepal and South Asia. Kathmandu: Ratna Pustak Bhandar.

NDC, (2016). National Dalit Commission 2016, Nepal Government.

NNDSWO, (2005). Ethnographic study on hill Dalit in Nepal, Nepal National Dalit Social Welfare Organization (NNDSWO), pp. 5152.

Wordpress, (2016). A Short Review on Gandharva Community in Nepal, retrieved from https://shakawath39.wordpress. com/2016/06/22/a-short-review-ongandharva-community-in-nepal/

Wagle, T. C. (2015). Gaine: Traditional Media man retrieved from https:// jesiwagle.wordpress.com/2015/03/13/ gaine-traditional-media-man/ 